Volume: 12 Issue: 1 Year: 2015

\title{
Inspection and teachers' emotions: An emotional evaluation of inspection
}

\author{
Binali Tunç ${ }^{1}$ \\ Yusuf İnandi ${ }^{2}$ \\ Bülent Gündüz $z^{3}$
}

\begin{abstract}
In the study, inspection is discussed in relation to the teachers' feelings and emotions it creates before inspection, during inspection and after inspection process. Teacher's emotions have been investigated intentionally as emotional side of education has been neglected. Education is closely related to the emotions of teachers, who are the most important producers of educational activities.

Educational activities are reduced to standard activities and defined with simple explanations or single labels such as 'good-bad', 'successful-unsuccessful', 'adequate-inadequate'. Inspection causes emotions to be neglected. Moreover, recently, it has been discussed that there are approaches and systems that suggest constant and multi-dimensional inspection instead of traditional inspection. Qualitative research model was used to understand of teacher emotions. A semi structured form was used for the 38 primary school teachers' interviews. After teacher interviews were completed, we analyzed and compared the interviews. Participants' expressions were checked in terms of correctness, potential validity and reliability problems such as misinterpretation.

The results of the study can be summarized as follows: There were no positive expressions related to the emotional impact of inspection on teachers. In addition, teachers felt that the inspectors were stressed, anxious, uneasy, accusatory, coercive, looking for defect and areas of unsuccessful teaching performance. Most of teachers reported that being observed and evaluated caused them to have negative emotions.

Teachers' perceptions about inspection are found to be negative. There are no statements that indicate there is a positive impression of inspection on teachers. The emotions that are experienced before inspection: pressure, hurry, stress, concern, tension, anxiety, worry, uncertainty; during inspection: stress, tension, anger, loss of strength, humiliation and lack of self-efficacy, and after inspection: relaxation, stress, sorrow, anger, fury, meaninglessness, disappointment. The single positive emotion that the teachers use to describe an inspection is "relaxation".
\end{abstract}

Keywords: Inspection; control; teachers' emotions; Turkey

\footnotetext{
${ }_{1}^{1}$ Assoc. Prof., Mersin University, Faculty of Education, Department of Educational Sciences, tunc75@gmail.com

${ }^{2}$ Assoc. Prof., Mersin University, Faculty of Education, Department of Educational Sciences, inandiyusuf@gmail.com

${ }^{3}$ Assist. Prof., Mersin University, Faculty of Education, Department of Educational Sciences, bgunduz27@gmail.com
} 
Tunç, B., İnand1, Y., \& Gündüz, B. (2015). Inspection and teachers' emotions: An emotional evaluation of inspection. International Journal of Human Sciences, 12(1), 554-568. doi: 10.14687/ijhs.v12i1.2807

\section{Introduction}

In the study, inspection is discussed in relation to the feelings and emotions it creates. It has been aimed to understand teachers' perceptions about inspection and inspectors, and how their emotions were influenced before inspection, during inspection and after inspection. Education is closely related to the emotions of teachers, who are the most important producers of educational activities. Ball (1993) states that teacher' performances are reduced to standard activities and defined with simple explanations or single labels such as "good-bad", "successful-unsuccessful", "adequateinadequate". Recently, it has been discussed that there are approaches and systems that suggest constant and multi-dimensional inspection instead of traditional inspection. As Hargreaves (2000) indicates, teachers are continuously observed and supervised only by means of technical arrangements such as rationalization in the educational process and making efforts for standardization, determining aims and performance.

The emotional impacts of inspection on teachers have been highlighted directly or indirectly in the studies. The discussions related to inspection and the results of inspection studies emphasize negative sides of inspection. However, these negative elements are associated with the application of inspection such as policy, program, number and adequacy of inspectors, judgments about inspection (Brimblecombe \& Ormston, 1995; Chapman, 2000; Ehren \& Visscher, 2008; Gilroy \& Wilcox, 1997; Lowe, 1997; Rosenthal, 2004). In these studies, the inquiries about the emotional component of inspections are very limited.

A very similar situation can be seen in the studies that have been conducted in Turkey. One such study highlights that the inspectors cannot fulfill their roles at an expected level (Tunç, 2001). Gökalp (2010) also states that the inspectors are not capable and competent enough. In Kahraman (2003) and Isslek's (2007) studies, it was found that the inspectors do not follow ethical principles. The inspectors influence the teachers' motivation negatively and cause anxiety (Ciğer, 2006) and the inspection causes panic, stress and lack of motivation (Dündar, 2005; Aky1ldı, 2007). The most conspicuous point in the studies was the way the inspection was conducted; yet the inquiries about emotional effects of inspection were ignored. In the studies mentioned above, inspection was seen as a process that was necessary and the criticisms about inspection were associated with various inspection models, procedures and inspectors' behaviours. However, it has been designated that the reflections of inspection on the emotional dimension of educational process have not been directly discussed and dealt with as a subject in the researcher's agenda. At the core of these studies, there is not an inquiry into the interaction between inspection and humane dimensions on the basis of teachers' emotions. 
Tunç, B., İnand1, Y., \& Gündüz, B. (2015). Inspection and teachers' emotions: An emotional evaluation of inspection. International Journal of Human Sciences, 12(1), 554-568. doi: 10.14687/ijhs.v12i1.2807

In Turkey, the educational activities and practices are organized and controlled by the central government. The "education inspectors", employed by the Ministry of National Education (MoNE), conduct inspections of private and public educational practices and activities. The MoNE Inspection Board regulations define the duties and responsibilities of inspectors in terms of providing the consistency of teaching activities, national aims and societal culture. However, recently, in addition to central inspection, there is a transition towards multi-dimensional and constant control that includes participation of stakeholders. Teachers are ultimately evaluated on the basis of academic success based on national examinations. The activities of teachers have to be in line with the specified standards. Compliance with the standards is controlled in a multidimensional way. However, the transition to this multi-dimensional approach is not totally completed; therefore, the impact of this model is not fully understood. For this reason, in the present study, the impact of inspection is studied in the context of traditional inspection applications.

\section{Inspection and emotional aspects of education}

Teacher's emotions are important components of emotional aspect in education. Nias (1996) states that it is not possible to exclude emotions while interacting with students in the school or classroom, as acting with emotions is a part of teachers' work. It is built on emotions to a great extent both in teaching and learning process. Bullough and Pinnegar (2009) indicate that individuals who remember their teachers with love signals the strong bonds between emotion and the teaching-learning process. For this reason, Bullough and Pinnegar's (2009) question is very meaningful: Does this reciprocal love result from, for example, the documents being prepared appropriately, plans being made very well and written neatly, teaching materials being used well, strict discipline and control, and instructions being followed correctly?

Intensive emotional interactions between teachers and students can take place in any normal day. Teachers' interactions with colleagues, inspectors, students and parents influence teaching and learning process (Zembylas, 2003). As Hargreaves (1998a) indicates, teaching is a job that should be professed with desire and love. Qualified teachers are passionate in their relationship with their students, as they do more than teaching educational content that is approved or determined by standards. As Hargreaves (1998b) emphasizes, none of the parents wants their children to be educated by unhappy, nervous, anxious, hopeless and stressed teachers and these expectations of parents do not change according to the era or culture.

In practice, education is infused with "emotion"; however, inspections limit education to a standard and formal activity. In other words, although it is known that teaching and learning process occur 
Tunç, B., İnand1, Y., \& Gündüz, B. (2015). Inspection and teachers' emotions: An emotional evaluation of inspection. International Journal of Human Sciences, 12(1), 554-568. doi: 10.14687/ijhs.v12i1.2807

by means of emotions, it is dealt with as a formal matter ignoring the emotional qualities of that process. The compulsion of making educational activities technical are constituted by the inspection based on negative acceptance related to human being. Burton (1930) regards the role of inspection as a technical service and expertise to improve students' learning and increase teachers' effectiveness and efficiency. In this approach, it is accepted that people's living and working together necessitate control and inspection. This statement points the direct or indirect activities of inspection that have been maintained thus far.

Criticisms of inspection are made in terms of its nature. As Webb (2005) indicates, controlling is the inseparable or inevitable part of inspection although different methods and materials have been used in inspection applications throughout history. Those who criticize the inspection phenomenon identify the inspection process as a control mechanism that disciplines the education staff with either prize or punishment (Ball, 1997; Hall \& Noyes, 2009; Perryman, 2009; Webb, 2005; Jeffrey \& Woods, 1996). As Perryman (2006) states, teachers being evaluated to control them is the nature of inspection. As Webb (2005) indicates, inspection is not only a natural way of collecting data about the workings of system or a passive determination of a case but also an agent that shapes understandings and practices.

The inspection system is mostly carried out by the mechanism of punishment and partially by the mechanism of prize. In inspection, teachers are categorized as "good" or "bad". The dominance of punishment is an indication of inspection quality that tends to determine "bad" teachers (Webb, 2005). This determination brings to mind an important question: can inspection, be conducted without impacting the emotions? The answer is another aspect of teacher-student polarity, which Freire $(2008,50)$ expresses as compulsory polarities in education: inspector-teacher. In this polarity, the teacher is conditioning his existence to a student's lack of knowledge experience, which overlaps with the inspector conditioning his existence with the teacher's deficiencies and mistakes. In this polarity, teachers regard their own existence as the primary condition for the inspector's existence.

The emotional impacts of inspection also result from the exclusive hierarchical structure. Although there has been no hierarchical superiority of inspectors recently, the emotions will be influenced as long as the evaluation process continues. As Woods and Jeffrey (1998) state, as long as the judgments about teachers are made open to public and this way of judgment continues, its impact upon teachers' emotions will continue. Thus, there is much criticism about applications of traditional inspection. It is said that the hierarchical and short-term applications of traditional inspection influence the interaction between teachers and inspectors negatively. Therefore, more 
Tunç, B., İnand1, Y., \& Gündüz, B. (2015). Inspection and teachers' emotions: An emotional evaluation of inspection. International Journal of Human Sciences, 12(1), 554-568. doi: 10.14687/ijhs.v12i1.2807

friendly control models should be developed. Due to these friendly models, teachers will be controlled with periodic test results, lists of exam scores and multiple inspection reports (evaluation by students, parents, colleagues and administrators) and the teachers will be controlled with longterm and detailed surveillance (Gewirtz, 2000). In this way, "cold" and "negative" aspects of traditional inspection will be removed (Webb, 2005). Nonetheless, it is stated that new control approaches make inspection constant process based evaluation and for this reason, negative emotional impacts of inspection on teachers will be constant. The fact that administrators, students and parents evaluate teachers continuously causes constant surveillance by providing reproduction of surveillance (Webb, 2005).

As Hargreaves (1998a) indicates, inspection increases pressure and stress on teachers. The fact that teachers are controlled by mechanical process evaluation tools such as checklist, aims, standards, procedures, files, documents, and indexes will negatively influence the milieu in which they interact with students emotionally. Hargreaves (1998b) states that the standardized aims and processes create feelings of inadequacy, burnout, anger, guilt and other negative emotions. Nias (1996) states that teachers' emotions increase and intensify when their activities are questioned and examined.

Purpose: This study purposes to explore the emotional impact of inspection on the primary teachers before inspection, during inspection and after inspection in Turkey.

\section{Method}

\section{Research Design}

For the understanding of teachers' emotions during inspection, a qualitative research model was used. Qualitative research method was applied through which teachers can realistically express their emotions in their own words. Via interviews, the study aimed to determine teachers' perceptions related to the inspection and inspectors. Besides, emotions they experience before inspection, during inspection and after inspection are investigated. Teachers' perception about inspection, inspectors and emotions they experienced were sought in a realistic and holistic way. Thus, teachers' perceptions about inspection and the emotional reflections of inspection on them can be clarified in detail.

\section{Sample}

The interviews were carried out with 38 primary school teachers. The primary school teachers were chosen because the students in primary school are in an emotionally-intense period and primary schools are inspected frequently. The interviewed teachers were chosen especially from different 
Tunç, B., İnand1, Y., \& Gündüz, B. (2015). Inspection and teachers' emotions: An emotional evaluation of inspection. International Journal of Human Sciences, 12(1), 554-568. doi: 10.14687/ijhs.v12i1.2807

socio-economic environments because profiles of teachers, students and environmental conditions can influence teachers' points of view about inspection.

\section{Research Instrument}

A semi structured question form was used for the interviews. Firstly the numbers of inspection which teachers have experienced were asked, and teachers were asked to evaluate the inspection without mentioning and considering their own experiences of inspection and inspectors behaviours. Then, they were interviewed about their perceptions of the inspection process and inspectors' behaviours. Later, teachers were asked about how they perceive inspection that becomes more dominant before inspection, during inspection and after inspection.

\section{Validity and reliability}

The validity and the reliability of interviews form are provided with peer debriefing and preinterviews. The pre-interviews were conducted to see whether questions were appropriate to the aim of the study or not. After teacher interviews were completed, we analyzed and compared the interviews. The responses gained were evaluated in terms of their consistency with inspection and then it was negotiated with the participants. Thus, participants' expressions were checked in terms of correctness, potential validity and reliability problems such as misinterpretation.

\section{Procedure}

Each interview lasted 25-40 minutes and they were carried out with sound recording. The interviews were conducted in the 2011 fall semester by researchers. The interviews were conducted with teachers having various seniorities. Teachers had been inspected at least four times and 28 times at most. It was thought that this would yield a wider spectrum of experiences with inspections and teachers' evaluations of the nature and practices of inspection.

\section{Findings}

Teachers first responded to the questions related to determining teachers' perceptions about inspection and inspectors. Then, the emotions that the teachers experienced in the inspection process were categorized under three headings; before inspection, during inspection and after inspection.

\section{Inspection, inspectors and teacher emotions}

The teachers criticize negatively the inspectors and the applications of inspection. Some teachers emphasized that nature of inspection is related to a controlling system. One of the teachers indicated that there is a difference between control mechanisms in education and other institutions: 
Tunç, B., İnand1, Y., \& Gündüz, B. (2015). Inspection and teachers' emotions: An emotional evaluation of inspection. International Journal of Human Sciences, 12(1), 554-568. doi: 10.14687/ijhs.v12i1.2807

There is an inspection system that controls teachers periodically. Also when there is a complaint or trouble, the inspectors come and start an inquiry... However, when I think of doctors, police and other government employees, there aren't any periodic inspection... Why is there such a system in education?... (Teacher 1, five times inspected)

The fact expressed by the teacher that they are controlled with an extra process while other government employees are not subjected to such a process emphasizes the controlling aspect of educational inspection. Another teacher's opinion was that the inspection exists due to the perception that the teachers are not trusted:

I don't accept that inspection is a right process. The inspectors treat us like we were guilty people and they try to oppress us. A society that does not trust their teachers cannot make any progress... (Teacher 25, 10 times inspected)

Teachers' criticisms related to inspection are based on their experiences in the inspection process they have been involved in. The most agreed point related with inspection is that inspection is a mechanism that controls education by an outsider; therefore what is happening in education cannot be completely understood.

What a teacher is doing can't be totally understood by a person who observes the event from outside and who isn't part of it. The inspectors run true to form. They evaluate everything according to ideal criteria. The ones who should evaluate us should be in our own activity. (Teacher 3, 14 times inspected)

Most of the teachers' criticism about inspection is focused on amount of paperwork, strict bureaucracy, tendency in standardization and it may have traumatic impacts on teachers.

The inspectors spend too much time on documents; they waste their time doing formality work. As a result of this, they don't have enough time to deal with teaching... (Teacher 10, 20 times inspected)

... The inspectors use lack of documents in detail as an excuse and blame us and we lose our motivation. (Teacher 4, 13 times inspected)

Inspection seems meaningless; being criticized for unnecessary and empty documents creates a feeling of meaninglessness. I don't feel like a teacher but like a potential guilty person who is being driven into a corner... This damages my self-confidence. The inspectors cause me to feel inadequate and unsuccessful. So can I be a good teacher? (Teacher 28, 23 times inspected)

Some of the teacher's in this study claimed that they are aware of the fact that the formalist aspect of inspection aims to make teaching standard, but it is not possible to constitute uniformity totally: 
Tunç, B., İnand1, Y., \& Gündüz, B. (2015). Inspection and teachers' emotions: An emotional evaluation of inspection. International Journal of Human Sciences, 12(1), 554-568. doi: 10.14687/ijhs.v12i1.2807

What is the aim of inspection conducted via documents? I think that their evaluation way of teachers who have devoted their years to education by looking at a few documents is an insult because every human being has his/her unique character and behaviour... (Teacher 1, five times inspected)

Another teacher point out the variety of education itself and life, by criticizing the disadvantage of the uniformity in the inspection:

All of the students have features which are different from each other and all of the teachers have unique personalities. When you enter the classes, you see that the same events are dealt with discussed and evaluated differently... To make these into a unique shape, a standard isn't possible and it isn't true either. (Teacher 24, 10 times inspected)

The negative perceptions related to the practices of inspection provide us some clues about how the inspection reflects upon teachers' emotions. It has been explored that the teachers are influenced negatively by the inspection.

\section{Teachers' emotions before inspection}

The emotional impacts of inspection start with the news of inspection and intensify.

I feel more pressure and tension before inspection. When I look around, I feel the same tension of most teachers. (Teacher 6, 11 times inspected)

I am afraid of making mistakes and I flounder. When I hear the news of inspection, I just think of it... My motivation for teaching is greatly reduced. (Teacher 14, 11 times inspected)

...An unnecessary atmosphere of tension emerges. Everybody, including students, knows that inspectors will come. The students easily notice that the teachers make hurried efforts to organize the classroom bulletin board and photocopy the documents. (Teacher 9, four times inspected)

It is very conspicuous that teachers experience intensive emotions and tension before inspection no matter how experienced they are. An experienced teacher's statement points out that the intensity of emotion based on inspection continues although he has a great deal of experience in teaching:

...before inspection, everybody prepares intensively. Although I have done teaching for many years, being inspected creates tension. (Teacher 38, 19 times inspected)

The teachers propounded that their state of emotion is directly connected to the inspection applications and inspectors' behaviours they have experienced. It is understood that stress and anxiety generally result from the fact that the teachers do not know what they experience will happen in the inspection. One teacher points out that stress and anxiety experienced before inspection results from unnecessary details which are focused on: 
Tunç, B., İnand1, Y., \& Gündüz, B. (2015). Inspection and teachers' emotions: An emotional evaluation of inspection. International Journal of Human Sciences, 12(1), 554-568. doi: 10.14687/ijhs.v12i1.2807

I experience stress before inspection. What will they say? What will they criticize? I feel anxious about which sentence they will criticize. (Teacher 1, five times inspected)

It is stated that one of the important sources of anxiety is the inspectors' behaviours that make the teachers uncertain about the process in the future:

Our not knowing the expectations of the inspectors create uneasiness ...each inspector has different expectations. The inconsistency between their expectations creates mistrust. Therefore, I feel anxious about how the inspectors will evaluate my performance. (Teacher 33, 14 times inspected)

The emotional impacts of paperwork on the teachers' emotions before inspection are emphasized:

...In the school, we feel a great deal of stress and hurry. All of the other work is delayed; there is a state of emergency. The teachers try to prepare documents that prove that they have done their job very well... (Teacher 2 , five times inspected)

...the teachers just think of their own problems, they forget the students... (Teacher 9, four times inspected)

One teacher mentions the reflections of the preparation before inspection on his life outside the school:

While I am making preparations before inspection, my communication with my friends reduces... When we talk to each other, we just say "the inspector will come this week"... (Teacher 12, four times inspected)

One of the teachers (Teacher 10, 20 times inspected) resembles preparations before inspection to the "rehearse of actors". This expression depicts the state of emotions in the school before inspection.

The emotions teachers experience before inspection are; pressure, burry, stress, concern, tension, anxiety, worry, uncertainty.

\section{Teachers' emotions during inspection}

The emotional impacts of inspection become more evident and distinct during inspection. It is emphasized that emotional intensity before inspection increases continuously during inspection. Some teachers express that the emotional intensity of inspection results from being observed:

What kind of emotional state do you experience, when you are controlled and observed? ... Someone comes and observes you, takes notes and you see... (Teacher 11, four times inspected)

Being aware of the inspectors creates anxiety and concern. (Teacher 7, 12 times inspected) 
Tunç, B., İnand1, Y., \& Gündüz, B. (2015). Inspection and teachers' emotions: An emotional evaluation of inspection. International Journal of Human Sciences, 12(1), 554-568. doi: 10.14687/ijhs.v12i1.2807

These expressions are indications of how surveillance can influence the people's state of emotion. Another teacher emphasizes the impacts of surveillance on himself and students:

Neither the teacher nor the students can feel relaxed. We cannot teach as we desire. Under stress and oppression, how can you feel relaxed when you know there is someone observing you? I feel anxious about what my deficiencies are... I become stressed because I think of which deficiencies he will find. (Teacher 3, 14 times inspected)

The anxiety that results from uncertainty before inspection turns into tension and nervousness during inspection:

The administrators are watchful and they control whether there is something missing. They don't want anyone to wander around and do something that is different from the routine. The state of haste and concern is very evident... The students feel tense and stressed due to the teachers' emotional state. (Teacher 4, 13 times inspected)

Another point on which the teachers agree with each other is that everything in the school during inspection is different from the normal routine. The difference is being in an insincere good teaching atmosphere. Some teachers state that this tension reflects negatively on the quality of teaching:

The teachers warn the students before the observation of the class. There are even some teachers who provide the questions and their answers to the students... Sometimes, unsuccessful students are warned not to draw attention. (Teacher 35, 24 times inspected)

As another teacher indicates, the lessons during the inspection are very different from the lessons in which the inspectors' do not attend:

... The teachers who shout at the students start caring about students and enact emphatic and sympathetic behaviours with a pretended courtesy. (Teacher 30, 15 times inspected)

It has been discerned that the perception of the inspectors as people who do not have good intentions is widespread. The quality of inspection is said to be dependent on personal features such as personality, educational background, political views which proves that the teachers do not like the inspectors' arbitrary behaviours. Two of the statements about the inspectors in the following paragraphs have proved this fact:

... They behave in an irritating, disappointing way. The inspectors don't understand the teachers do their duties like inspectors and they spend as much effort as possible. They don't respect us. (Teacher 20, 10 times inspected) 
Tunç, B., İnand1, Y., \& Gündüz, B. (2015). Inspection and teachers' emotions: An emotional evaluation of inspection. International Journal of Human Sciences, 12(1), 554-568. doi: 10.14687/ijhs.v12i1.2807

... I think that the inspectors feel they have to find deficiency and mistake. They are afraid of saying something is done well and appreciating well. They behave in a way that causes teachers to lose their motivation. (Teacher 36, 13 times inspected)

The teachers state that the impacts of inspection are not limited with the school; it influences their lives outside the school as well:

I continue feeling the stress and tension of inspection at home; my family is negatively influenced by this process. I think that I have done injustice to my family, but the reason causing this injustice is the inspection. (Teacher 16, 10 times inspected)

... The stress and anger felt in the inspection reflect on my home life... (Teacher 28, 23 times inspected)

The emotions expressed by the teachers that they experience during inspection are; stress, tension, anger, loss of strength, bumiliation and lack of self efficacy.

\section{Teachers' emotions after inspection}

The teachers expressed that they feel relaxed after inspection. Some teacher's stated that they experience relaxation irrespective of the inspection process being good or bad for them:

I feel happy because I get rid of the inspection... The inspection reports that are written without being analyzed or spoken about does not interest me. (Teacher 3, 14 times inspected)

Some teachers say that they experience anger and fury in addition to relaxation:

The relaxation and anger occur according to the situation. Relaxation occurs if the inspection is objective and the inspectors are constructive; otherwise, fury and anger occur. However, generally, fury and anger occur. (Teacher 5, 13 times inspected)

Some of the teachers state that the relaxation after inspection allows for a return to efficiency. Regardless of how the inspection ended, either well or badly, they get back in to circulation, to their normal life:

After inspection, I feel relaxed, while teaching and lecturing, everything becomes good. Teachers and students can turn back to their normal state. The oppression or pretending ends. (Teacher 13, 24 times inspected)

Some teachers state that the intensive preparations and practices before and during inspection were tiring and exhausting for them:

Document preparations, preparing the students for the process, trying to do our best during inspection are tiring and wearing. (Teacher 34, 18 times inspected) 
Tunç, B., İnand1, Y., \& Gündüz, B. (2015). Inspection and teachers' emotions: An emotional evaluation of inspection. International Journal of Human Sciences, 12(1), 554-568. doi: 10.14687/ijhs.v12i1.2807

The results of inspection are used as a kind of oppression upon teachers. One teacher' expressions about inspection points out how people's relationships are influenced:

After the inspection ...the administrator blames teachers for the negative aspects of reports and uses the reports to warn teachers. After the inspection, the teachers check and compare each other's reports; comments go on for a long time. Some comments on inspection such as favoritism, injustice, unfairness, uselessness are made by the teachers. (Teacher 6,11 times inspected)

Some of the emotional terms that the teachers use to express their emotions are as follows; relaxation, stress, sorrow, anger, fury, meaninglessness, disappointment.

\section{Conclusion}

In the research, teachers' perceptions about inspection are found to be negative. There are no statements that indicate there is a positive impression of inspection on teachers. By relying on teachers' responses, it can be claimed that teachers' belief in the functionality of inspection positively is very low.

The emotions that are experienced before inspection: Pressure, burry, stress, concern, tension, anxiety, worry, uncertainty; during inspection: Stress, tension, anger, loss of strength, bumiliation and lack of self efficacy, and after inspection: Relaxation, stress, sorrow, anger, fury, meaninglessness, disappointment. These emotions highlight the anxiety derived from uncertainty before inspection and stress, and weariness from tension. Before inspection, it is understood that the teachers experience an emotional intensity caused by the state of being controlled. During inspection, the teachers continue to experience emotions that are similar to before the inspection. However, one of the most conspicuous findings of the research is that none of the emotions expressed before inspection and during inspection is positive. The single positive emotion that the teachers use to describe an inspection is "relaxation". However, it must be noted that the relaxation is experienced after inspection. The teachers who experience relaxation claim that the inspection creates emotional intensity and tension, and the transition to normalization starts just after the inspection. The fact that relaxation is not experienced before and during inspection underscores that the emotional reflections of inspection are not positive.

The teachers criticize inspection because it is strict bureaucracy, amount of paperwork and tendency standardization. However, education is multi-dimensional and very dynamic so the standardization of educational activities is not suitable. Teachers reported that educational activities cannot be standardized; strict bureaucratic and document-based inspection is ignoring the 
Tunç, B., İnand1, Y., \& Gündüz, B. (2015). Inspection and teachers' emotions: An emotional evaluation of inspection. International Journal of Human Sciences, 12(1), 554-568. doi: 10.14687/ijhs.v12i1.2807

emotional aspect of education. The environment where teaching takes place and the differentiation of teachers and students' personal characteristics conflict with the fact that the inspection has the tendency to standardize and control.

As the teacher emphasizes, the inspection system suggests that the educational situations, which are filled with humanity and emotions, should be rationalized and deprived of human values. In education, the fact that should not be forgotten is that the neglecting the humane side of teaching creates an important risk for the future of society. Especially in recent years, protection and guarding are attached importance and teaching is neglected. It is sensible to listen to teachers and students about this issue. The teachers regard the students as a whole. They should develop close relationships with them and this can be succeeded by means of natural behaviours. In Woods and Jeffrey's (1998) study a teacher expresses that it is necessary to behave like a child by establishing empathy in order to communicate with pupils, pointing out that as long as the inspection continue the it should be considered various complex issues for the sake of efficacy of the process.

It is obvious that the teachers who participated in the present study do not like being controlled and inspected. Instead of developing control mechanisms in which the teachers can be controlled more, the teachers should be trusted more and they should be given more authority as well as responsibility which could be more effective in terms of teaching and learning.

Making plans in detail and trying to realize them restrict the teachers' will to decide and act on their own. The processes of planning and making decisions should include emotional factors and individual aims. The management approaches in which emotions are taken into account should be adopted. As Hargreaves (1998b) indicates, human relationships and cultural dimensions should be considered in a school's reconstruction. The planners of policies should avoid rationalization enterprises that negatively influence the environment in which the teacher and administrators interact emotionally with the students or they can be interested in students by means of checklists, aims, meetings and documents.

In the present study, the teachers are found to focus on the behaviours for inspection. During the inspection, schools are observed and teachers try to prove that they are in a good school (Perryman, 2007). In order to meet the expectations of the inspection, the teachers try to exaggerate their activities by doing the same things again and again.

As Freire asserts, education should not be built on contrasts. It is easy to understand that the reciprocal results of the interaction built on existentialist contradictions (inspector-teacher) are negative. This study reveals the nature of negative contradiction between teachers and inspectors 
Tunç, B., İnand1, Y., \& Gündüz, B. (2015). Inspection and teachers' emotions: An emotional evaluation of inspection. International Journal of Human Sciences, 12(1), 554-568. doi: 10.14687/ijhs.v12i1.2807

and how this contradiction will go on directly or indirectly due to the nature of human being and the process. If this is the truth, what is the best way to overcome this confusion? The answer is that it is better to consider Freire's recommendation. To overcome this contradiction in education, the best option is to make the teachers free with control; otherwise, inspection will always be needed, and teachers' activities do not provide a sufficient contribution. If the education environments in which the teachers develop their efficacy, and they will use this for the society are not provided, the continuous and close control mechanisms continue to be a factor that restricts teachers and education. As the teachers indicated, it is evident that activating the intrinsic inspection mechanisms instead of extrinsic inspection mechanisms by developing sensitivity, responsibility, and consciousness seems more meaningful.

\section{References}

Aky1ldı, S. (2007). İlkögretim denetmenlerinin etik davranıslarnna iliskin ögretmen görüslerinin değerlendirilmesi. [Evaluation of teachers' opinions about the ethical behavior of primary school inspectors.] Yüksek Lisans Tezi. Diyarbakır: Dicle Üniversitesi Sosyal Bilimler Enstitüsü.

Ball, S.J. (1993). Education policy, power relations and teachers' work. British Journal of Educational Studies, 41(2), 106-121.

Ball, S.J. (1997). Good school/bad school: Paradox and fabrication. British Journal of Sociology of Education, 18(3), 317-336.

Brimblecombe, N., \& Ormston, M. (1995). Teachers' perceptions of school inspection: A stressful experience. Cambridge Journal of Education, 25(1), 53-62.

Bullough, R.V., \& Pinnegar, S. (2009). The happiness of teaching (as eudemonia): disciplinary knowledge and the threat of performativity. Teachers and Teaching: theory and practice, 15(2), 241-256.

Burton, W.H. (1930). Supervision. The American Journal of Nursing, 30(8), 1045-1052.

Case, P., Case, S., \& Catling, S. (2000). Please show you're working: a critical assessment of the impact of OFSTED inspection on primary teachers. British Journal of Sociology of Education, 21(4), 605-621.

Chapman, C. (2000). Improvement, inspection and self-review. Improving Schools, 3(9), 57-63.

Ciğer, M. (2006). Kahramanmaraş ili ilkëğretim müfettişlerinin ders denetimi surecinde gösterdikleri davranıslarn ögretmenleri güdülemesine iliskkin ögretmen ve müfettiş görüsleri. [Kahramanmaras province' primary school teachers and inspectors' opinions about the inspectors' behaviours to motivate teachers.] Yüksek Lisans Tezi. Ankara: Ankara Üniversitesi Eğitim Bilimleri Enstitüsü.

Dündar, A.A. (2005). İlkögretim okullarnda yapılan teftişin okul bassarısı ve gelisimi üzerine etkisi. [The effect of the primary school inspections on the performance and development of the schools.] Yüksek Lisans Tezi. Ankara: Gazi Üniversitesi Eğitim Bilimleri Enstitüsü.

Ehren, M.C.M., \& Visscher, A.J. (2008). Improvement relationships between school inspections, school characteristics and school improvement. British Journal of Educational Studies, 56(2), 205-227.

Freire, P. (2008). Eqilenlerin Pedagojisi. [Pedagogy of the oppressed.] 6. Basım. Çev. Hattatoğlu ve Özbek. Ankara: Ayrintı Yayınları. 
Tunç, B., İnand1, Y., \& Gündüz, B. (2015). Inspection and teachers' emotions: An emotional evaluation of inspection. International Journal of Human Sciences, 12(1), 554-568. doi: 10.14687/ijhs.v12i1.2807

Gewirtz, S. (2000). Bringing the politics back in: a critical analysis of quality discourses in education. British Journal of Educational Studies, 48(4), 352-370.

Gilroy, P., \& Wilcox, B. (1997). OFSTED, criteria and the nature of social understanding: a Wittgensteinian critique of the practice of educational judgement. British Journal of Educational Studies, 45(1), 22-38.

Gökalp, S. (2010). İlköğretim Müfettislerinin Öğretmen Teftislerindeki Denetim Görevlerini Yerine Getirme Derecelerine İliskin İlköğretim Okullarnnda Görev Yapan Öğretmenlerin Algzlarnnn Incelenmesi. [The analysis of primary school teachers perceptions on the inspectors' fulfillment levels control tasks.] Yüksek Lisans Tezi. Mersin: Mersin Üniversitesi Sosyal Bilimler Enstitüsü.

Hall, C., \& Noyes, A. (2009). New regimes of truth: the impact of performative school self evaluation systems on teachers' professional identities. Teaching and Teacher Education, 25, 850-856.

Hargreaves, A. (1998a). The Emotional Practice of Teaching. Teaching and Teacher Education, 14(8), 835-854.

Hargreaves, A. (1998b). The emotional politics of teaching and teacher development: with implications for educational leadership. International Journal of Leadership in Education, 1(4), 315-336.

Hargreaves, A. (2000). Mixed emotions: teachers' perceptions of their interactions with students. Teaching and Teacher Education, 16, 811-826.

Jeffrey, B., \& Woods, P. (1996). Feeling deprofessionalised: The social construction of emotions during an OFSTED inspection. Cambridge Journal of Education, 26(3), 325-343.

Kahraman, N. (2003). Illkëgretim müfettislerinin mesleki etik ilkeleri ve bu etik ilkelere uyma düreyleri. [The professional ethical principles of primary school inspectors and comply with etbical requirements.] Yüksek Lisans Tezi. Ankara: Ankara Üniversitesi Eğitim Bilimleri Enstitüsü.

Lowe, G. (1997). Improvement through inspection? Paper presented at the British Educational Research Association Annual Conference. (September 11-14, 1997: University of York) Fourth OFSTED Symposium. Retrieved May 5, 2011, from http://www.leeds.ac.uk/educol/ documents/000000465.htm.

Nias, J. (1996). Thinking about feeling: the emotions in teaching. Cambridge Journal of Education, 26(3), 293-306.

Perryman, J. (2006). Panoptic performativity and school inspection regimes: disciplinary mechanisms and life under special measures, Journal of Education Policy, 21(2), 147-161.

Perryman, J. (2007). Inspection and emotion. Cambridge Journal of Education, 37(2), 173-190.

Perryman, J. (2009). Inspection and the fabrication of professional and performative processes. Journal of Education Policy, 24(5), 611-631.

Rosenthal, L. (2004). Do school inspections improve school quality? OFSTED inspections and school examination results in the UK. Economics of Education Review, 23, 143-151.

Tunç, B. (2001). Illkögrretim müfettişlerinin problem çözme süreci açısından rollerini gerçeklesstirme biçimleri. [The form of the primary school inspectors' perform their roles in terms of problem-solving process.] Yüksek Lisans Tezi. Edirne: Trakya Üniversitesi Sosyal Bilimler Enstitüsü.

Webb, P.T. (2005). The anatomy of accountability. Journal of Education Policy, 20(2), 189-208.

Woods, P., \& Jeffrey, B. (1998). Choosing positions: Living the contradictions of OFSTED. British Journal of Sociology of Education, 19(4), 547-570.

Zembylas, M. (2003). Emotions and teacher identity: A poststructural perspective. Teachers and Teaching: theory and practice, 9(3), 213-238. 